\title{
Performances of a Yard-Scale Surface Flow Wetland Vegetated with Echinochloa Crus-Pavonis in the Removal of Nutrients and Faecal Bacteria from Domestic Wastewater
}

\author{
Théophile Fonkou (corresponding author) \\ Laboratory of Applied Botany, University of Dschang, Faculty of Science, \\ Department of Plant Biology, PO Box 377 Dschang, Cameroon \\ Tel: 237-9727-0152Ｅ-mail: tfonkou@yahoo.fr

\section{Martin Lekeufack} \\ Laboratory of Applied Botany, University of Dschang, Faculty of Science, \\ Department of Plant Biology \\ E-mail: leke_martin@yahoo.com
}

Fabrice Teguimdje

Laboratory of Applied Botany, University of Dschang, Faculty of Science,

Department of Plant Biology, PO Box 377 Dschang, Cameroon

E-mail: Teguimdjef@yahoo.fr

Received: May 14, 2013 Accepted: May 30, 2013

doi:10.5296/jbls.v4i2.3880ＵRL: http://dx.doi.org/10.5296/jbls.v4i2.3880

\begin{abstract}
Several macrophytes are being tested in experimental wetlands systems in Cameroon, for the treatment of domestic wastewater. The aim of the present research was to assess the performances of a yard scale surface flow wetland vegetated with Echinochloa crus-pavonis,
\end{abstract}


in the removal of nutrients and faecal bacteria from primarily treated effluent. A wetland vegetated with the macrophyte and a non-vegetated wetland (control) were continuously fed with primarily treated domestic wastewater at organic loading rates varying from 20.74 to $27.15 \mathrm{~g} \mathrm{BOD} / \mathrm{m}^{2} /$ day in dry season and the rainy season for two consecutive years. Physicochemical and microbiological characteristics of water were monitored at the entries and exits of the wetlands alongside the growth attributes of the young plants during each season. Plant densities in the bed increased with time during each season of the experiment, and not significantly lowered during the following season after harvest. Percentage removal ranges of $89-95 \%$ and $75-93 \%$ were observed for faecal bacteria during the dry and the rainy seasons respectively in the vegetated beds, as compared to ranges of $25-71 \%$ and $24-73 \%$ recorded in the control bed. The same trend was observed for nitrates and orthophosphates with removal rates of up to $62 \%$ and $82 \%$ respectively as compared to $40 \%$ and $47 \%$ recorded in the control. The vegetated bed was significantly more efficient than the control in the reduction of several parameters, but this varied with seasons.

Keywords: Surface flow wetland, Echinochloa crus-pavonis, Removal, Nutrient, Faecal bacteria

\section{Introduction}

Lack of proper sanitation coupled to high population growth in urban areas of developing countries has adverse effects on water quality (Denny, 1997; Kivaisi, 2001). About $51 \%$ of African countries suffer from severe environmental pollution, with $78 \%$ of towns lacking adequate services for the evacuation and treatment of wastewater (Morel, 1996). In many cases, sewage from industries and agglomerations is piped or drained into the nearby aquatic ecosystems. As a result, surface and ground water are heavily polluted (Fonkou et al., 2005a).

Limitations with natural wetlands and the absence of operational wastewater treatment systems in most developing countries have led to a growing interest in wetland technology (Kern and Idler, 1991; Tchobanoglous 1987; Agendia, 1995). Wetland treatment systems offer several advantages such as the simplicity of construction, the low operational costs, and the capability to withstand excess organic and hydraulic loads (Wolverton, 1987). These advantages are especially important in warm tropical climates that are conducive for high biological activities (Kivaisi, 2001).

There are two common types of constructed wetlands: the Surface Flow (SF) and the Subsurface Flow (SSF) wetland systems (Mankin, 2003). The SF system is characterized by water flowing at a shallow depth above the surface of the substrate. The SSF or vegetated submerged bed wetland contains a porous substrate with water flowing below it. Macrophytes in the wetlands filter particles, and are known to absorb nutrients produced by the biological activities of microorganisms symbiotically associated to their underground parts (Hammer, 1989; Reed et al., 1995; Ingersoll and Baker, 1998; Brix, 1999; Liu et al., 2000; Wetzel, 2000). Pathogens in the wastewater degrade over time or are mitigated in the soil by naturally occurring microorganisms (Kadlec and Knight, 1996).

The application of wetland technology for wastewater treatment in tropical regions remains 
limited despite the recognized advantages of higher operational temperatures leading to better treatment efficiencies (Kivaisi, 2001). In Cameroon, macrophytic lagoon systems using floating aquatic macrophytes were found to be very efficient in the removal of nutrients and pollutants in domestic wastewater (Agendia, 1995; Kengne et al., 2003). Less attention has nevertheless been focused on emergent wetland plants, which may have longer growing periods with important biomass production, leading to possible long term absorption and bioaccumulation of pollutants. Preliminary studies have identified and postulated many local aquatic plants growing in natural wetlands for the treatment of domestic wastewater (Fonkou et al., 2005b).

E. crus-pavonis is suited for ensilage and is used as cattle fodder especially in India and areas of East Africa where it is sometimes cultivated for this purpose. In Egypt, this plant is used for the phytoremediation of saline and alkaline areas (Holm et al., 1977). In the aim of testing selected local macrophytes for their use in constructed wetlands for wastewater treatment, several plant species were collected from their natural environments and were tested in a yard scale constructed wetlands system. The biomass yields from these macrophytes alongside their performances in reducing nutrient contents from domestic wastewater were assessed with the aim of exploitation as fodder in the dry season (Fonkou et al., 2011; Lekeufack et al., 2012). The present paper focuses on the performances of E. crus-pavonis in the removal of nutrients and faecal bacteria from domestic wastewater, in a yard scale horizontal surface flow constructed wetland.

\section{Material and Methods}

\subsection{Site of Study}

This study was conducted in a yard-scale constructed wetlands system in the campus of the University of Dschang, located between latitudes $5^{\circ} 25^{\prime}$ and $5^{\circ} 30^{\prime}$ North and between longitudes $10^{\circ} 00^{\prime}$ and $10^{\circ} 5^{\prime}$ East in the Western Highlands of Cameroon. The climate in this region is of equatorial type with 4 months of dry season from mid-November to mid-March, and 8 months of rainy season from mid-March to mid-November. Annual precipitations estimates range between $1433 \mathrm{~mm}$ and $2137 \mathrm{~mm}$, while annual mean temperature is estimated at $20.8{ }^{\circ} \mathrm{C}$ with thermal amplitude of $2{ }^{\circ} \mathrm{C}$. Wastewater used in the study was collected from a small primary treatment plant receiving domestic liquid wastes from the students' residence. Part of the primarily treated wastewater was channelled into a $1.3 \mathrm{~m}^{3}$ gutter from where it was distributed to the experimental wetlands using PVC pipes.

\subsection{Design of the Experimental Wetlands}

Five wetlands of $3 \times 1 \times 0.6 \mathrm{~m}^{3}$ were constructed using cement blocks (figure 1 ). The insides of the structures were plastered with concrete, then Cement and Lankofuge ${ }^{\mathrm{TM}}$ for water tightness. A $1 \%$ slope was respected on the bottom of each wetland bed to ease the movement of water from the inlet to the outlet. Gabions of $30 \mathrm{~cm}$ made up of stones of 5-8 cm diameter were arranged at the inlet and outlet zones of the wetlands, while a drainage layer of about $10 \mathrm{~cm}$ was arranged at the bottom. The outlet structures were adjustable to enable the regulation of the water level in the substrate. The main filter substrate was a $40 \mathrm{~cm}$ column of sand having 


\section{MInstitute Macrothink $_{\text {Int }}$}

particles size $<2 \mathrm{~mm}$ (figure 2). Results presented in this paper are those of CW5, that was vegetated with E. crus-pavonis and CW3 that was used as the non-vegetated control wetlands. The inflow rate was estimated at 205 litres/day. The bed capacity measured from the porosities of the gabion and the sand filter was 923 litres. The hydraulic retention time (HRT) of 4.5 days was then calculated from the equation $H R T=\frac{\text { Bed Capacity }}{\text { Inflow rate }}$, as stated by Lorion, 2001. The constructed wetlands served as a secondary treatment associated to the existing primary treatment in which only the particle filter and the digester were still functioning.

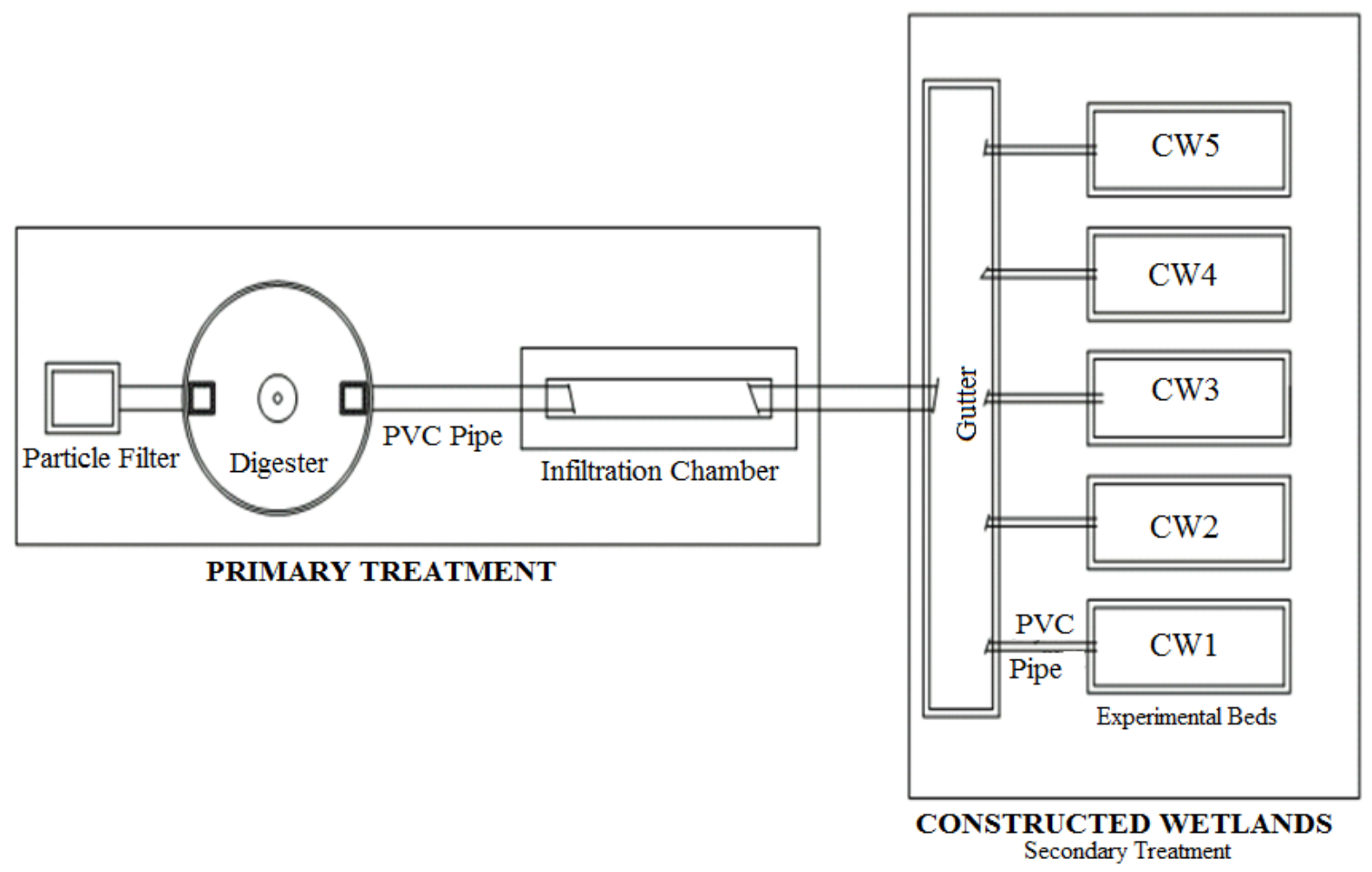

Figure 1. The yard-scale setup of the experimental wetlands' system.

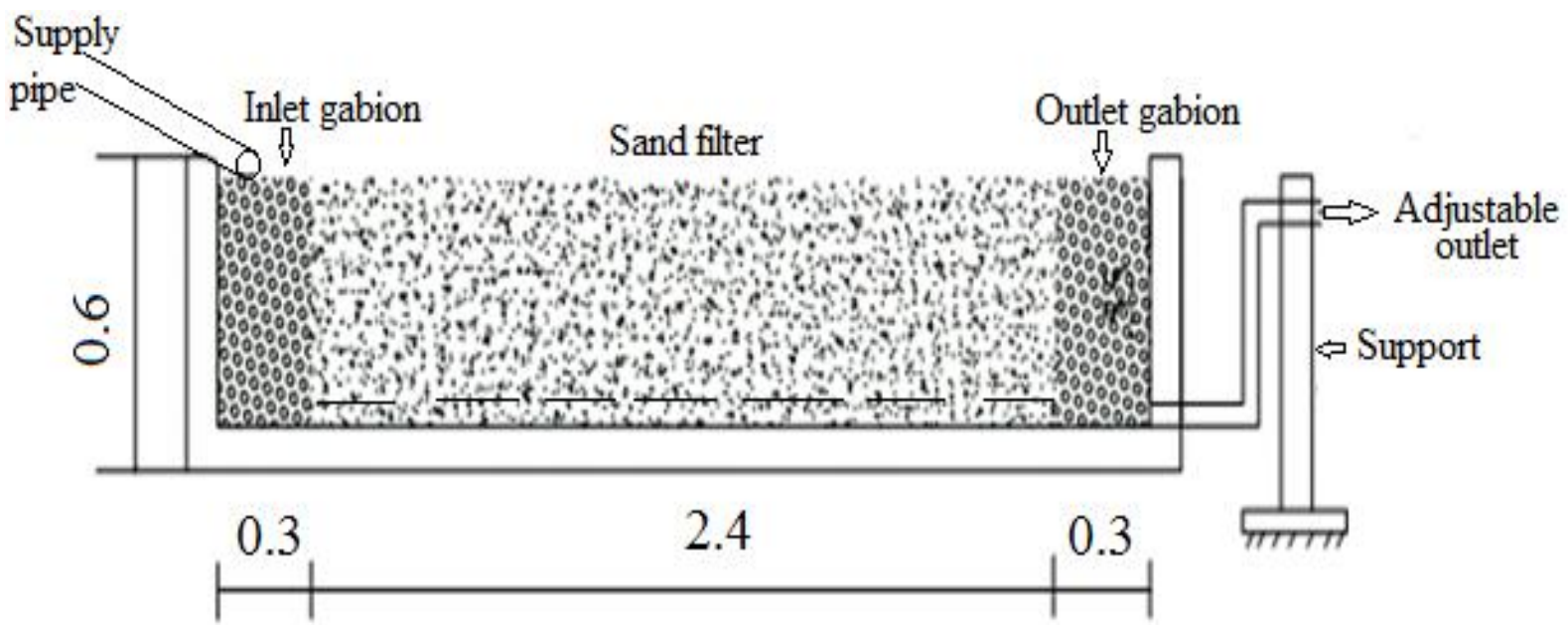

Figure 2. Longitudinal section of the horizontal surface flow wetland. 


\subsection{Setting up the Experiment}

Young shoots of E. crus-pavonis were collected from a natural wetland and washed in fresh water. After weighing, shoots were planted in CW5 at a density of $14 \mathrm{shoots} / \mathrm{m}^{2}$ (figure 3 ). Primarily treated effluent from a conventional treatment plant was collected in a gutter and allowed to directly flow into the wetlands at organic loading rates varying from 20.74 to 27.15 $\mathrm{g} \mathrm{BOD} / \mathrm{m}^{2} /$ day in dry season and the rainy season of two consecutive years. The characteristics of the primarily treated effluent are presented in tables 1 and 2. After a 2 months domestication period during which the shoots grew to a standing vegetation considered having good biological activity, wastewater was allowed to flow continuously into the bed at a loading rate of $85.43 \mathrm{~L} . \mathrm{m}^{-2}$. day ${ }^{-1}$ in a horizontal surface flow (HSF) configuration. During each season of the year, the plants were harvested when $50 \%$ were observed to have flowered in the bed.
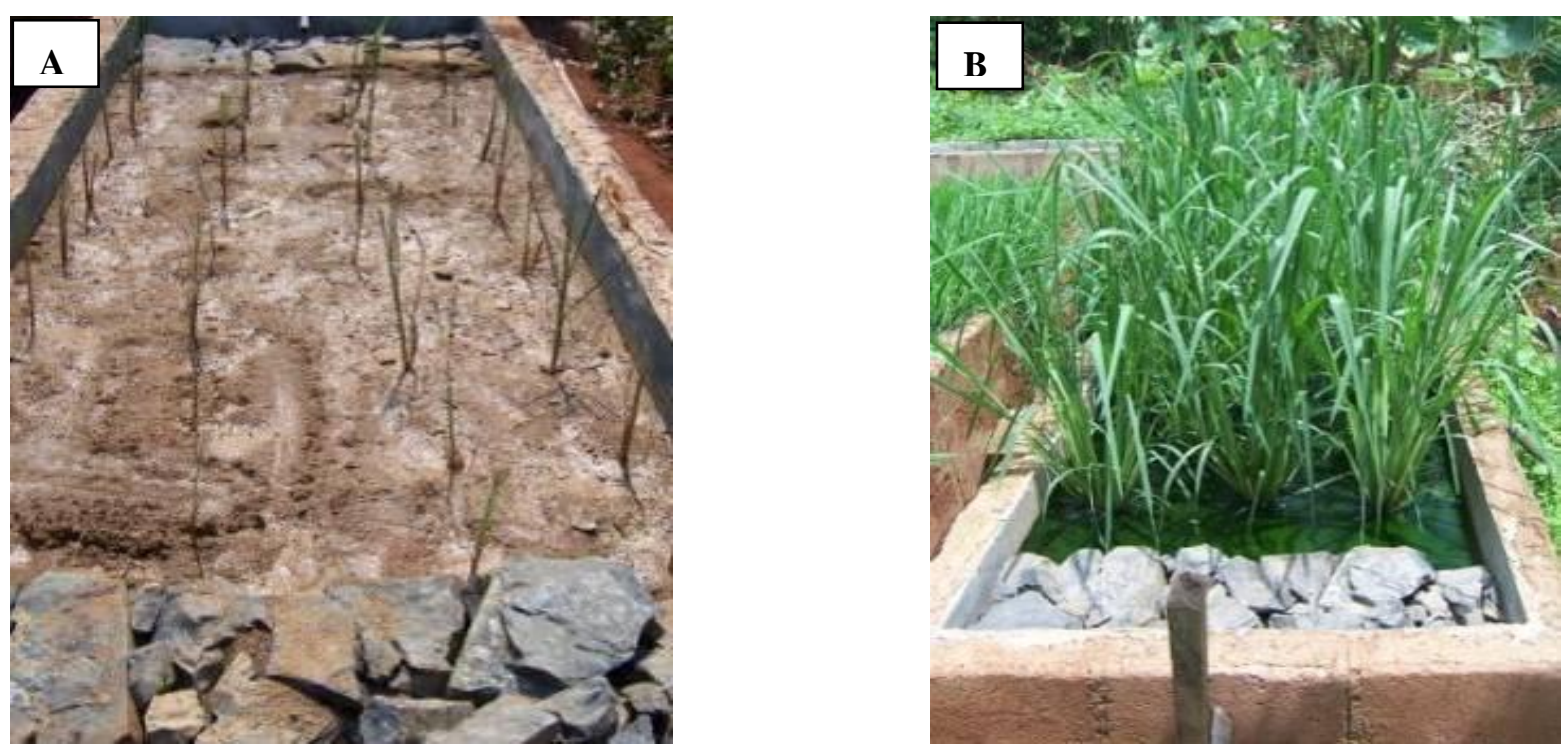

Figure 3. Aspects of the vegetation in the wetland after planting of young shoots (A) and at the start of the performance analysis (B).

Table 1. Physicochemical characteristics of the primarily treated effluent used in the constructed wetland (mean \pm SEM, $n=26$ )

\begin{tabular}{|l|l|l|}
\hline Parameters & Dry season & Rainy season \\
\hline $\mathrm{CND}(\mu \mathrm{S} / \mathrm{cm})$ & $3705 \pm 383$ & $2294 \pm 354$ \\
\hline Colour $(\mathrm{PtCo})$ & $585 \pm 91$ & $616 \pm 121$ \\
\hline Turbidity $(\mathrm{FTU})$ & $266 \pm 3$ & $311.3 \pm 72$ \\
\hline $\mathrm{TSS}(\mathrm{mg} / \mathrm{L})$ & $697 \pm 63$ & $425 \pm 58.7$ \\
\hline $\mathrm{NO}_{3}{ }^{-}(\mathrm{mg} / \mathrm{L})$ & $8.7 \pm 2$ & $5.1 \pm 1.2$ \\
\hline $\mathrm{PO}_{4}^{-3}(\mathrm{mg} / \mathrm{L})$ & $113 \pm 18.7$ & $94.3 \pm 33$ \\
\hline $\mathrm{SO}_{4}{ }^{-2}(\mathrm{mg} / \mathrm{L})$ & $14.5 \pm 3$ & $7.8 \pm 3.5$ \\
\hline $\mathrm{COD}(\mathrm{mg} / \mathrm{L})$ & $545 \pm 11$ & $582 \pm 21.4$ \\
\hline BOD5 $(\mathrm{mg} / \mathrm{L})$ & $229 \pm 5$ & $244.6 \pm 9$ \\
\hline
\end{tabular}




\section{MInstitute Macrothink $_{\text {Int }}$}

Table 2. Average counts $(\log 10$ units CFU/100 ml) of faecal contaminant indicators (Total coliforms, TC; Faecal coliforms, FC; and Faecal streptococci, FS) in the primarily treated effluent used in the constructed wetland (mean \pm SEM, $n=26$ )

\begin{tabular}{|l|l|l|}
\hline Parameters & Dry season & Rainy season \\
\hline TC & $7.36 \pm 0.22$ & $7.48 \pm 0.27$ \\
\hline FC & $7.27 \pm 0.34$ & $7.57 \pm 0.35$ \\
\hline FS & $7.76 \pm 0.43$ & $7.38 \pm 0.56$ \\
\hline
\end{tabular}

\subsection{Water Sample Collection and Microbiological Analyses}

Water samples were collected at two weeks intervals throughout the research period at the inflow and the outflow of the CW3 (non-vegetated control) and CW5 (vegetated with $E$. crus-pavonis) wetlands, from November 2009 to October 2011. Sterile laboratory glass bottles of $500 \mathrm{ml}$ were used to collect water samples that were immediately transported for analyses.

In the laboratory, manipulations were carried out in strict conditions of sterility. In aseptic conditions, $1 \mathrm{ml}$ of homogenous raw sample was measured and added into $9 \mathrm{ml}$ of sterile distilled water to have 1:10 dilution. This same operation was repeated from the first dilution until the desired dilution was obtained (1:10, 1:100, 1:1000, 1:10 000, etc). The pipette was always rinsed between dilutions to avoid contamination. The distilled water was sterilized by autoclaving in sealed sterile glass bottles for 15 minutes at $121^{\circ} \mathrm{C}$.

Total coliforms, faecal coliforms and faecal streptococci were detected by membrane filtration following standard methods (American Public Health Association (APHA), 1998; Centre d'Expertise en Analyse Environnementale du Québec (CEAE), 2005). AC Cellulose Membranes Filters ${ }^{\mathrm{TM}}$ with pore-size $0.45 \mu \mathrm{m}$ were used on a WHEATON filtering Funnel ${ }^{\mathrm{TM}}$ attached to a CM $1500^{\mathrm{TM}}$ vacuum pump.

Appropriate sample volumes, in three different dilutions $\left(10^{-2}, 10^{-3}\right.$ and $\left.10^{-4}\right)$ for effluent or $\left(10^{-3}, 10^{-4}\right.$ and $\left.10^{-5}\right)$ for influent were filtered and incubated for each parameter. This was to ensure having at least a plate with colony counts ranging between 20 to $100 \mathrm{CFU}$ (Hench et al., 2003). Samples for faecal coliforms were incubated on Difco ${ }^{\mathrm{TM}} \mathrm{m}$ FC prepared Agar in Petri dishes at $44.5^{\circ} \mathrm{C}$ for $24 \mathrm{hrs}$ (Karathanasis et al., 2003, Karim et al., 2008). Thereafter, all characteristically blue and central white hollowed blue colonies were counted as faecal coliforms.

Samples for faecal streptococci and total coliforms were respectively incubated on $\mathrm{BBL}^{\mathrm{TM}}$ Bile Esculin and Tergitol ${ }^{\circledR} 7$ Agars at $35^{\circ} \mathrm{C}$ for 48 hrs (Karathanasis et al., 2003). Thereafter all characteristically black and yellow colonies were respectively counted for faecal streptococci and total coliforms. Each result was expressed as number of Colony Forming Units per $100 \mathrm{ml}$ (CFU/100ml) of sample.

\subsection{Measurement of Physicochemical Parameters}

The physicochemical parameters including total suspended solids (TSS), Nitrates, 


\section{Mll Macrothink}

Journal of Biology and Life Science

ISSN 2157-6076

2013, Vol. 4, No. 2

Orthophosphates, Chemical Oxygen Demand (COD), and 5-days Biochemical Oxygen Demand $\left(\mathrm{BOD}_{5}\right)$ were measured according to procedures described by Hach Company, 2004).

The $\%$ reduction of each parameter in the bed was obtained using formulae below:

$\%$ reduction $=\frac{C_{i}-C_{o}}{C_{i}} \times 100$, Where: $\mathrm{C}_{\mathrm{i}}=$ inlet value; $\mathrm{C}_{0}=$ outlet value

The treatment efficiency of the planted bed was compared with that of the control bed for each wetland system using the unpaired, one-tailed T-test. The two-tailed Pearson correlation test was used to evaluate the relationship between the growth and the contributions of each plant to the treatment efficiency of the vegetated beds in the system. The Student T test was performed at $0.05 \%$ probability level to compare the means of the parameters measured at the inflows and the outflows of the wetlands. As concerns microbial population density, data were $\log _{10}$ transformed to obtain the geometric means.

\section{Results}

\subsection{Changes in the Height and Density of Plants in the Bed}

Figure 4A presents the changes in height of E. crus-pavonis in the wetland during the first year of experiment. The height of E. crus-pavonis increased very rapidly in the dry season, from $0.93 \mathrm{~m}$ at the start of parameters measuring to $1.65 \mathrm{~m}$ at the end of the season. This increase in height like the density started dropping after two months of parameters analyses till the end of the dry season. In the rainy season, the young shoots which arose after the dry season harvest showed very healthy growth with the increase in height presenting almost a linear relationship. This figure clearly shows that the rate of increase in height was higher in the rainy season than in the dry season. At the time of harvest which marks the end of the season, the tallest plant was $2.65 \mathrm{~m}$ height.

In the dry season of the second year after harvesting E. crus-pavonis at the end of the rainy season of the first year, numerous new shoots arose and grew very rapidly and healthily. The plants growth showed almost the same trend in height increase but there was no net drop in height as in the dry season of the first year (fig. 4B). Plants here started flowering after two months of growth and by the end of the season almost all the plants in the bed had flowered. Moreover, some individuals especially those found near the inlet gabion of the wetland showed stunted growth such that, they flowered at very low heights ranging from 15-40 cm only. Generally, all records of plant growth parameters including the number of leaves per plants, leaf length and width and density in bed were generally higher compared to data recorded during the dry season of the first year. 

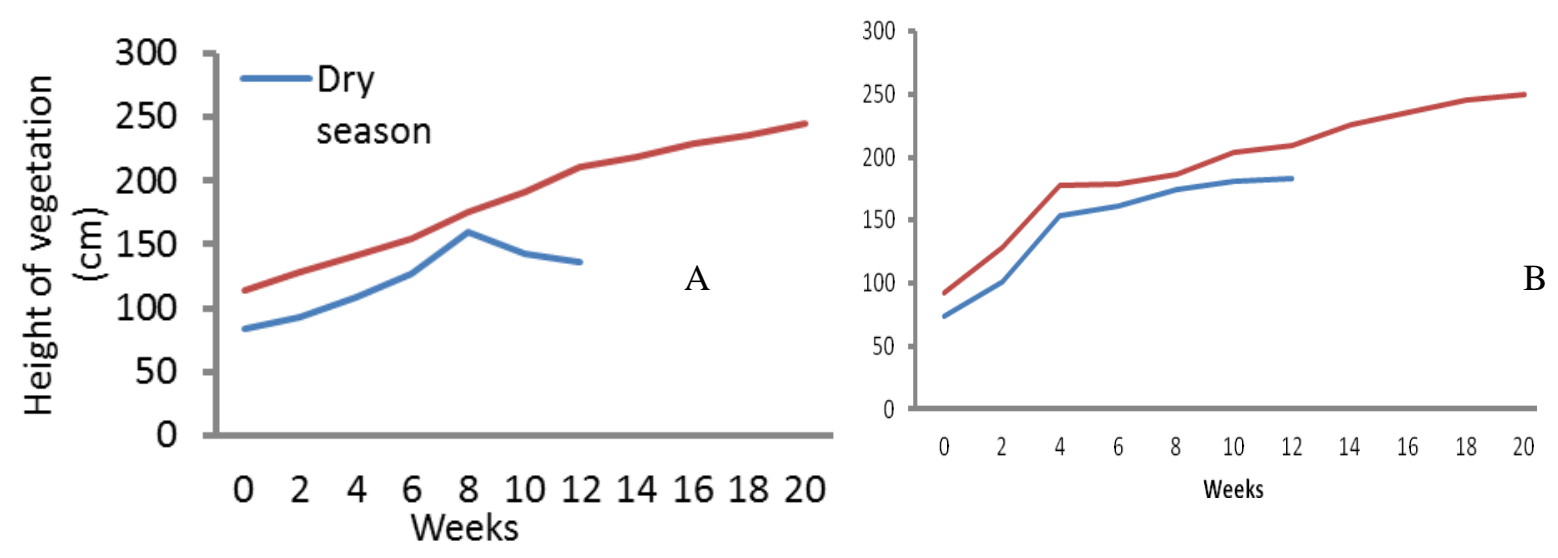

Figure 4. Changes in the height of the vegetation in the bed during the dry and the rainy seasons of the first year (A) and the second year (B)

The thirty-two young shoots of E. crus-pavonis transplanted in CW5 immediately entered into the growth phase where they grew and multiplied rapidly to produce a population density of 376 plants $/ \mathrm{m}^{2}$ two months after transplanting. After this period, the density of the plant continued to increase rapidly for one month after which it started dropping till the end of the dry season of the first year (fig. 5A). In the rainy season, the young shoots which arose grew rapidly without any inconveniency and covered the entire bed. At the start of parameters analyses, the density of plants in the wetland increased slowly to a density of 166 plants $/ \mathrm{m}^{2}$ at the end of the season.

In the second year when the plants were harvested to mark the end of the first year, the new shoots which arose grew rapidly and healthily colonizing the entire wetland. At the start of parameters measurement just one month after harvest, the wetland had a density of 186 plants $/ \mathrm{m}^{2}$. At the end of the dry season when the plants had flowered, the density was 517 plants $/ \mathrm{m}^{2}$. In the rainy season, the species had a slow rate of increase in density but, by the end of the season the density in the wetland was not less than that at the end of the dry season (fig. 5B). It is also seen that the rate of increase in density was more in the dry season than in the rainy season. But there was no significant difference between the two seasons statistically $(\mathrm{P}>0.05)$ 

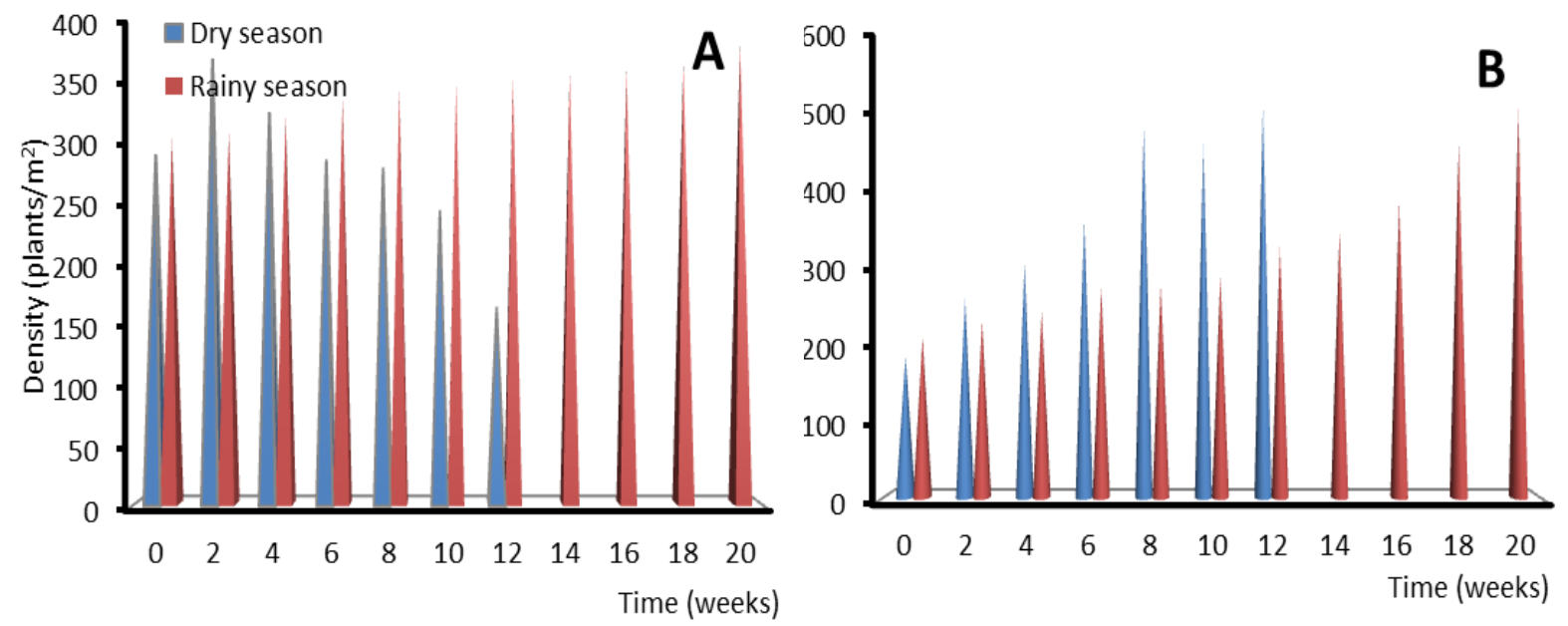

Figure 5. Evolution of plant density in the bed during the dry and the rainy seasons of the first year (A) and the second year (B)

\subsection{Removal of Faecal Bacteria}

The average removal of indicator bacteria at the outflow ranged between $86 \%$ and $95 \%$ in the vegetated wetland, and between $24 \%$ and $71 \%$ in the non-vegetated control during the first year (table 3). In the second year, this overall removal ranged between $75 \%$ and $94 \%$ in the vegetated wetland, and between $55 \%$ and $71 \%$ in the non-vegetated control (Table 4 ). As the wastewater passes through the vegetated wetland during the first year, the reduction of faecal coliforms varied from $0.01 \log$ units to $4.0 \log$ units in six weeks, but dropped to $0.63 \mathrm{log}$ units at the end of the season. In the control wetland, the highest reduction (1.2 log units) was obtained at the $4^{\text {th }}$ week (fig. 6A). During the second year, a similar variation was observed, with reductions ranging from $0.7 \mathrm{log}$ units to $3.0 \mathrm{log}$ units. Similar performances were observed for the non-vegetated control wetland during the two dry seasons (fig. 6B).
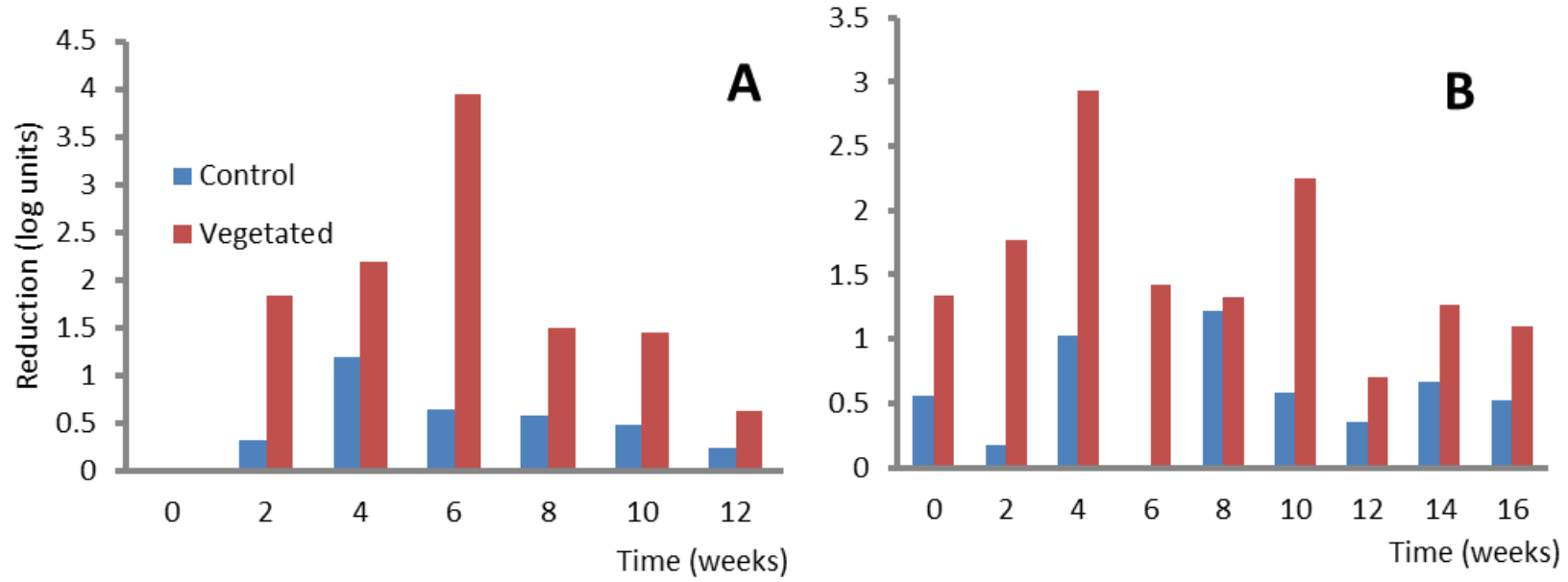

Figure 6. Reduction of the faecal coliforms counts in the vegetated and in the control wetlands during the dry seasons of the first year (A) and the second year (B). 


\section{Macrothink}

During the first year, reductions of faecal coliforms recorded in the vegetated wetland varied from $0.3 \log$ unit in the first week to peak of $2.09 \log$ units after 12 weeks, and then started dropping till $1.17 \log$ units reduction at the end of the season (fig. 7A). In the control, a similar trend was observed, with an increase from 0.12 to $1.2 \mathrm{log}$ units in 12 weeks, followed by a drop to $0.05 \log$ units at the end of the season. However, the Student's t-test revealed that the vegetated wetland was significantly more efficient $(\mathrm{P}<0.05)$ than the non-vegetated control.
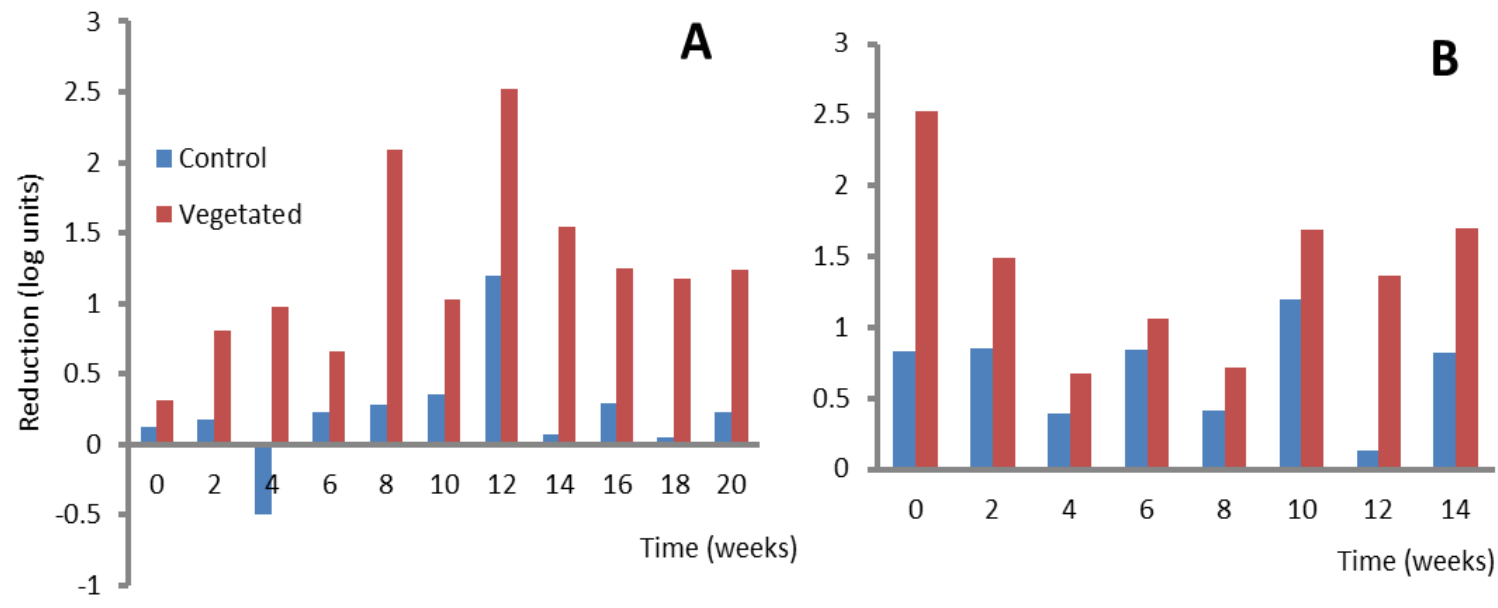

Figure 7. Reduction of the faecal coliforms counts in the vegetated and in the control wetlands during the rainy seasons of the first year (A) and the second year (B)

During the second year the variation in the reduction was not similar. In the vegetated wetland, it dropped from $2.53 \mathrm{log}$ units in the first week to $0.72 \mathrm{log}$ units after 8 weeks, and then increased to $1.7 \log$ units at the end of the season. In the control, the reductions instead increased from $0.83 \log$ units to $1.2 \mathrm{log}$ units' reductions after 10 weeks and then dropped to $0.82 \log$ units at the end of the season (fig. 7B). Comparing the performance of the wetlands in the rainy season of the first year with those recorded during the second year, there was no significant difference between the vegetated wetlands as well as the controls.

Table 3. Average percentage removals of faecal bacteria (Total coliforms, TC; Faecal coliforms, FC; and Faecal streptococci, FS) in the outflow of the vegetated and the control wetlands during the dry seasons of the two years of experiment

\begin{tabular}{|c|c|c|c|c|}
\hline \multirow{2}{*}{ Parameters } & \multicolumn{2}{|c|}{ First Year } & \multicolumn{2}{c|}{ Second Year } \\
\cline { 2 - 5 } & Vegetated & Control & Vegetated & Control \\
\hline T.C & $93.99 \pm 3.00$ & $25.69 \pm 9.79$ & $89.26 \pm 3.53$ & $59.1 \pm 12.5$ \\
\hline F.C & $95.00 \pm 3.70$ & $71.54 \pm 5.67$ & $94.61 \pm 1.97$ & $63.49 \pm 9.73$ \\
\hline F.S & $91.97 \pm 3.04$ & $54.73 \pm 11.90$ & $93.29 \pm 2.53$ & $55.02 \pm 7.24$ \\
\hline
\end{tabular}


Table 4. Average percentage removals of faecal bacteria (Total coliforms, TC; Faecal coliforms, FC; and Faecal streptococci, FS) in the outflow of the vegetated and the control wetlands during the rainy seasons of the two years of experiment.

\begin{tabular}{|c|c|c|c|c|}
\hline \multirow{2}{*}{ Parameters } & \multicolumn{2}{|c|}{ First Year } & \multicolumn{2}{c|}{ Second Year } \\
\cline { 2 - 5 } & Vegetated & Control & Vegetated & Control \\
\hline T.C & $88.18 \pm 3$ & $51.05 \pm 10.78$ & $75.37 \pm 5.80$ & $55.37 \pm 9.46$ \\
\hline F.C & $87.70 \pm 4.56$ & $43.57 \pm 7.98$ & $92.68 \pm 2.93$ & $73.05 \pm 7.87$ \\
\hline F.S & $86.34 \pm 4.03$ & $24.43 \pm 4.71$ & $93.05 \pm 198$ & $71.16 \pm 10.42$ \\
\hline
\end{tabular}

Faecal streptococci concentrations were not very variable at the outflow of the wetlands in the dry season of the first year (fig. 8A). However, the reduction in the number of colonies increased slightly from $0.78 \log$ units to $5.18 \log$ units after 10 weeks, and dropped to $0.5 \log$ units at the end of the season. A similar trend was observed in the control wetland but with peak on the $8^{\text {th }}$ week.
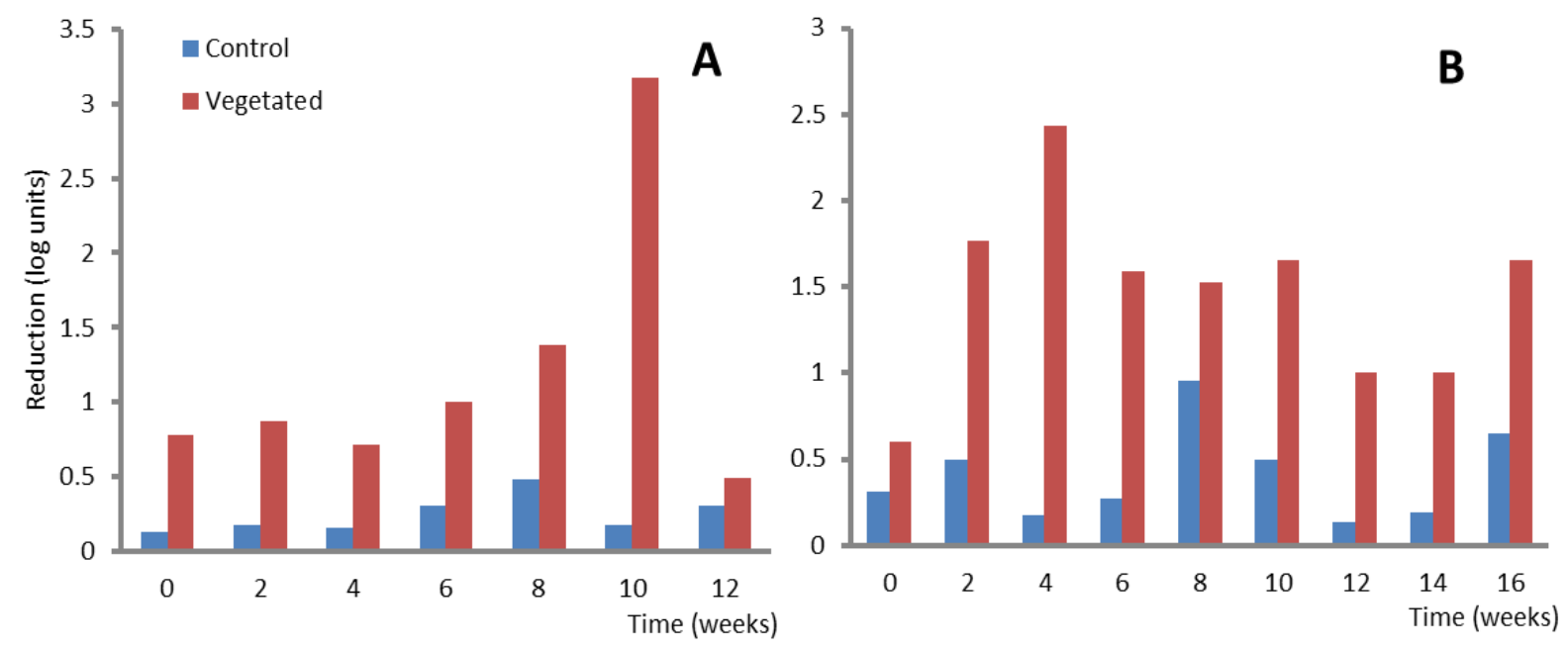

Figure 8. Reduction of the faecal streptococci counts in the vegetated and in the control wetlands during the dry seasons of the first year (A) and the second year (B)

During the second year, there was no consistent variability in the reduction of faecal streptococci counts in both the vegetated and the non-vegetated control (fig. 8B). In spite of the non-consistent variability at the outflow of the wetlands, there was an important statistical difference $(P<0.05)$ between the two wetlands. Also, there were no significant seasonal differences between the first year dry season and that of the second year even though the second year dry season appeared to be more efficient than that of the first year.

Figure 9 shows the evolution of the reductions of faecal streptococci counts in log units of CFU in the outflow of the vegetated and the non-vegetated control wetlands during the rainy season of the first year (A), and the rainy season of the second year (B). Figure 9A shows clearly that the vegetated wetland was highly more efficient $(P<0.05)$ than the control in the first year. 

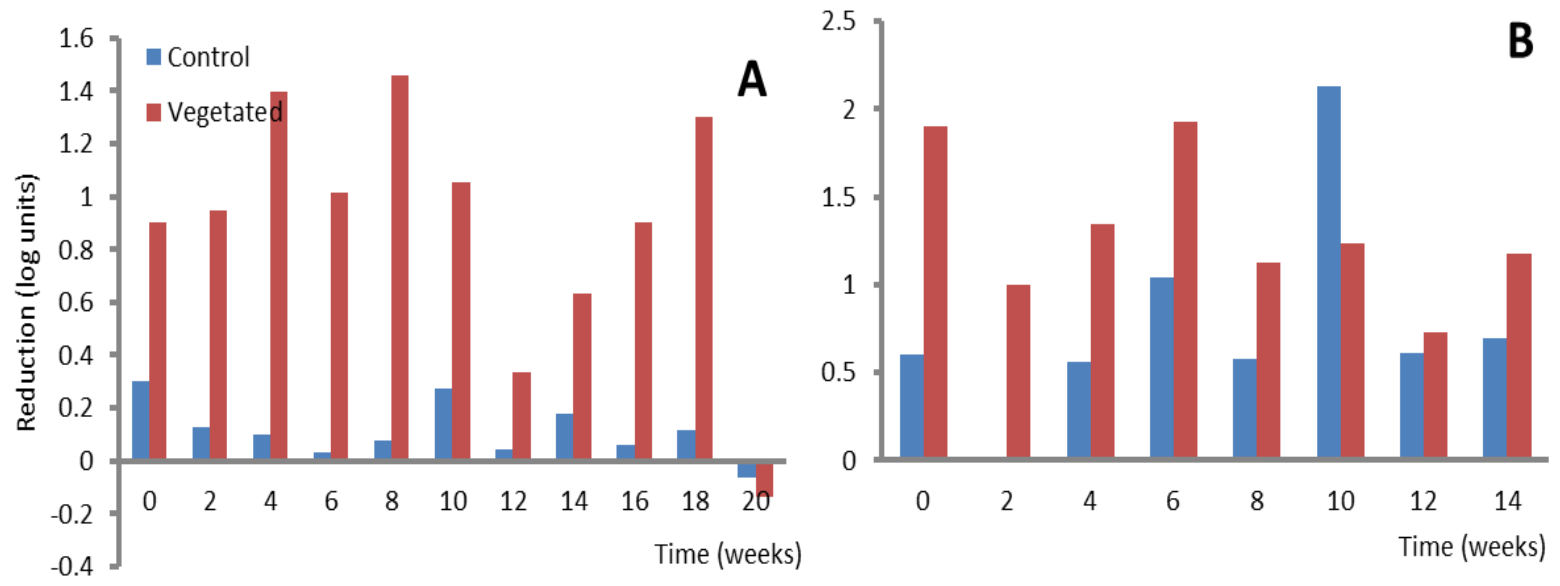

Figure 9. Reduction of the faecal streptococci counts in the vegetated and in the control wetlands during the rainy seasons of the first year (A) and the second year (B)

During the second year, the reductions increased from $1.9 \log$ units in the first week to $1.93 \mathrm{log}$ units after 6 weeks and then dropped to $1.2 \mathrm{log}$ units at the end of the season. A similar variability was observed at the outflow of the control and there was no significant difference between the performances of the two wetlands although the vegetated wetland appeared to be more efficient at all times. The statistical analysis also revealed no significant differences $(\mathrm{P}>$ 0.05 ) between the two seasons of the different years.

The evolution of the total coliforms reductions at the outflow of the wetlands during the dry seasons of the experimental period is presented in figure 10. During the first year, the reduction in total coliforms counts at the outflow of the vegetated wetland increased almost in a linear trend up to the $8^{\text {th }}$ week. After this week reduction decreased also in the same way till the end of the season. Even though there was no consistent trend in the reductions of total coliforms counts at the outflow of the control, the Student's t-test revealed significant differences ( $\mathrm{P}$ $<0.05)$ between the vegetated and the control wetlands during this season. The reduction on total coliforms counts in the dry season of the first year varied between 0.93 and 1.82 log units in the vegetated wetland giving an average reduction of $89 \%$, and between 0.02 and $0.3 \log$ units in the control with an average reduction of 59\%. The average reductions were 1.32 and $0.17 \log$ units respectively in the vegetated and control wetlands. 

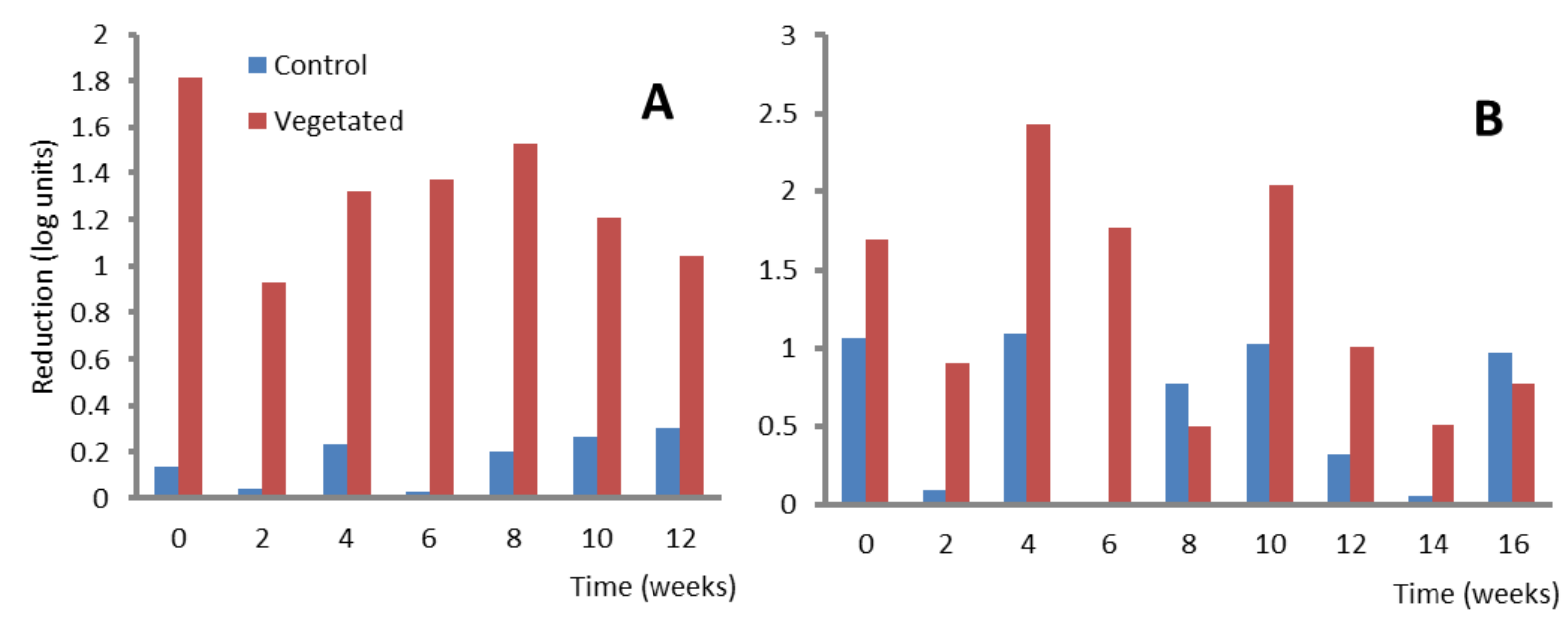

Figure 10. Reduction of the total coliforms counts in the vegetated and in the control wetlands during the dry seasons of the first year (A) and the second year (B)

In the dry season of the second year, there is a high variability with no consistent trend in the evolution of the reduction of total coliforms in both the vegetated and the control wetlands. In the vegetated wetland the reduction varied between 0.5 and $2.4 \log$ units whereas in the control it varied between 0.02 and $1.09 \log$ units. The average reductions were 1.29 and $0.6 \log$ units in the vegetated and control wetlands respectively. Comparing the two wetlands during this season, there was no significant difference between them $(\mathrm{P}>0.05)$. Also, the vegetated wetland in the dry season of the first year was in the average more efficient in the reduction of total coliforms than in the second year, but there was no significant difference between the two seasons $(\mathrm{P}>0.05)$.

Figure 11 presents the evolution of the reduction in total coliforms counts in the vegetated and control wetlands during the rainy seasons of the first year (A), and of the second year (B). In the first year, the reductions in the vegetated wetland presented a high variability throughout the season; changing from $0.62 \log$ units to $1.4 \mathrm{log}$ units. A similar variability is observed for the control wetland where the reduction throughout the season varied from 0.23 to $0.77 \log$ units. The T-test analysis revealed significant differences $(\mathrm{P}>0.05)$ between the vegetated and the control wetlands.

During the second year like in the first, the concentration of total coliforms was lowered more in the vegetated wetland than in the control. The reduction varied between 0.38 and $1.3 \log$ units in the vegetated wetland with an average reduction of $0.71 \log$ units while in the control, it varied between 0.07 and $1.3 \mathrm{log}$ units with an average reduction of $0.47 \mathrm{log}$ units, but the statistical analysis revealed no significant differences between the two wetlands. Comparing the two rainy seasons, there was no significant difference between them too. 

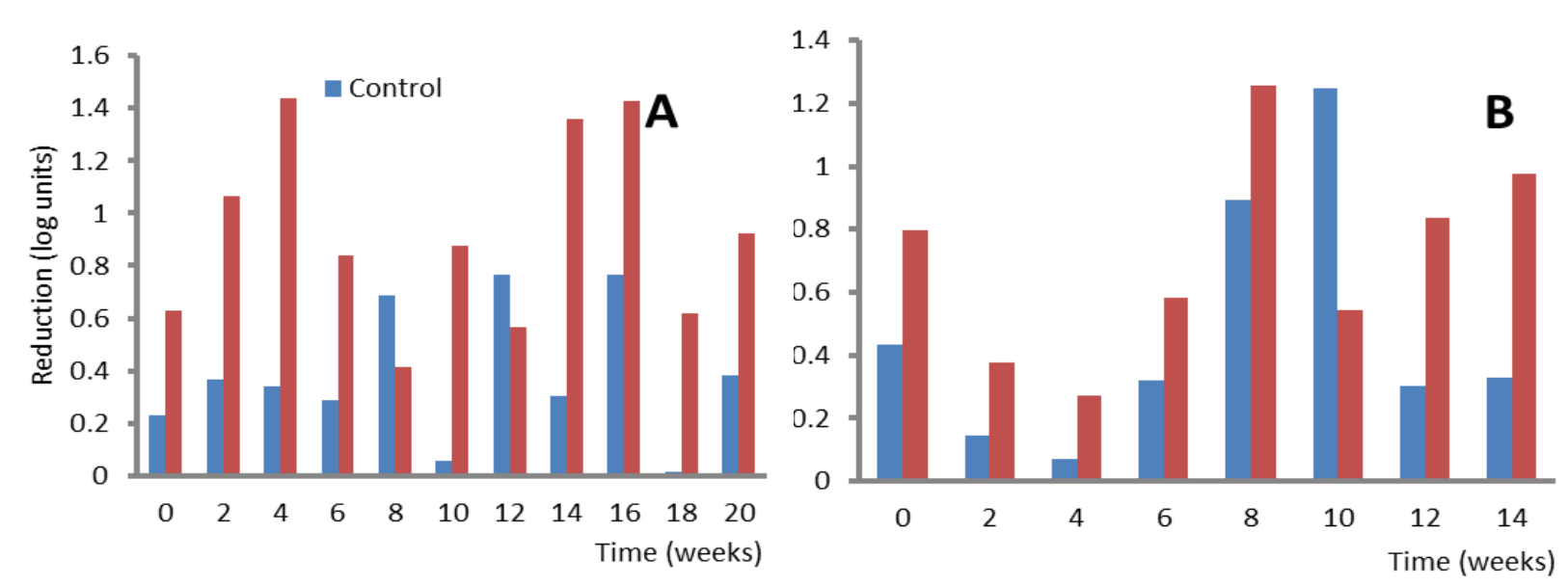

Figure 11. Reduction of the total coliforms counts in the vegetated and in the control wetlands during the rainy seasons of the first year (A) and the second year (B)

\subsection{Reduction Rates of Physicochemical Parameters}

During the dry season of the first year, the parameter with the highest removal rate was TSS $(74.78 \%)$, followed by nitrates $(63.69 \%)$, while the least reduction rate was recorded for phosphate. These removal rates followed the same trend in the control wetland with the least removal rate of $13.21 \%$ being recorded for conductivity followed by phosphate $(17.5 \%)$. The most reduced parameter in the control was TSS (68.38\%), and the nitrates were the nutrients with highest removal rates $(46.58 \%)$. The vegetated bed was always more efficient than the non-vegetated control in this season, but there was no significant difference $(\mathrm{P}>0.05)$ between the wetlands. Although the concentrations at the outflows were statistically different with the inflow, the differences between the outflows of the wetlands were not statistically significant. However, during the rainy season of the first year, the concentration of $\mathrm{BOD}_{5}$ at the outflow of the vegetated bed was significantly different $(P<0.05)$ from that of the control as well as the inflow.

During the dry season of the second year, the trend was very different from that of the first year. The phosphates were instead the nutrients with the highest removal rate $(80.51 \%)$ in the vegetated wetland followed by nitrate $(60.05 \%)$ and then the TSS). The conductivity was the parameter with least removal efficiency $(21.7 \%)$ in this wetland followed by the COD $(42.85 \%)$. In the control, the trend was not the same thus, the TSS was the parameter with highest removal rate $(76.52 \%)$ followed by the phosphate $(66.57 \%)$. However, the removals of the different parameters between the two wetlands were not statistically significant $(P>0.05)$. The vegetated wetland had higher efficiency in the reduction of nitrates than phosphates in the dry season of the first year, but not in the second year.

In the control wetland, the TSS remained the most reduced parameter and the conductivity the least reduced. Meanwhile in the vegetated wetland, the most reduced parameters were TSS in the first year and phosphate in the second year while conductivity remained the least reduced parameter in the dry season of both years.). 
In the vegetated wetland, the nutrient with the highest removal rates $(58.06 \%$ and $62.61 \%)$ respectively in the first and second years were the nitrates. The phosphates were removed at $(50.36 \%$ and $55.58 \%)$ respectively in the first and second years. The parameter with the highest removal rate $(91.48 \%)$ in first year, and $(86.47 \%)$ in the second year was the TSS. Conductivity remained the parameter with least removal rates in the rainy season of both years.

In the control wetland during the rainy season, the TSS was still the parameter with highest removal in both seasons $(86.19 \%$ and $78.75 \%)$ respectively in the first and second years. For the nutrients, nitrates had highest removal $(39.77 \%)$ in first year while phosphates were removed at $47.48 \%$ in the second year. In the rainy seasons, the vegetated wetlands were generally more efficient than the non-vegetated control but, statistical analyses revealed no significant differences $(P>0.05)$ between the wetlands in each season. Also, there were no significant differences $(P>0.05)$ between the performances of the wetlands in the rainy seasons of the different years.

During the second year, the $\mathrm{BOD}_{5}$ concentrations at the outflow of the vegetated bed were always less than those of the non-vegetated control. However, the concentrations in the dry season were statistically very different $(P<0.05)$ with the inflow but not with the non-vegetated control. In the rainy season of the same year just like in the first, the $\mathrm{BOD}_{5}$ concentrations at the outflow of the vegetated bed were statistically different from those of the inflow as well as those of the non-vegetated control.

\section{Discussion}

Plants densities in both the dry and rainy seasons of the second year were lower but not significant $(\mathrm{P}>0.05)$ than the densities in the first year, perhaps in respond to the harvest of the previous seasons. This observation is different from that of Morison et al. (2000) where, plant density was considerably higher in the next season as a reflection to harvest in the previous season.

In the wetland vegetated with E. crus-pavonis, the reduction of faecal bacteria was always higher than in the non-vegetated control. This confirms the previous reports that, the reduction of total and faecal coliforms under natural conditions with plants was always higher (Karpiscak et al., 1996; Thurston et al., 2001; Karim et al., 2008. It is well documented that, plants in wetlands excrete photosynthetic products and other organic compounds through their roots to enhance their symbiotic relationship with the soil micro-organisms (Tchobanoglous 1987; Andrews and Haris, 2000; Karjalainen et al., 2001; Gagnon et al., 2007). It is thought in this experiment that the presence of plants provided a nutrient rich environment at the rhizosphere zone. These enhanced the substrate's microbial density and activity in the wetland, leading to competition with the faecal bacteria or to the production of toxins which caused their elimination from the wastewater. These results can again supports the proposal that vegetation in wetlands through the root exudates activates the growth of ciliate protozoa which are predators of bacteria (Green et al., 1997; Lester and Birkett, 1999; Gagnon et al., 2007). The results also supports the assumed role of plants in generating micro-aerobic environment in the rhizosphere zone for the proliferation of aerobic bacteria which will surely be absent in the non-vegetated control (Weißner et al., 2002). The wetlands were more efficient in the reduction 
of faecal indicators during the dry season of the second than in the first year but, with no significant difference $(\mathrm{P}>0.05)$ between the two seasons. These results could have been due to the well-established natural flora in the systems. It also indicates that, the system constructed in series may have a good capacity to remove even pathogenic bacteria from wastewater more efficiently by the second year of functioning (Greenway, 2005). In the dry seasons, the reduction trends in the vegetated wetland as well as in the non-vegetated control were similar. This suggests that bacteria reduction in wetlands could be due to microbial competition and predation (Karim et al., 2008). Generally the reductions of faecal bacteria in the vegetated wetland ranged from 0.5 to $5 \log$ units in the first year and 0.6 to $2.5 \log$ units in the second year. These values are found within the range of values also reported by Arias et al. (2003) in a vertical flow constructed wetland system vegetated with Phragmites australis. These results are also similar to those observed by Karathanasis et al., 2003) and Torrens et al. (2009) in polycultured systems. In the control wetland, reductions in faecal bacteria counts were also high but not significant. These could only be attributed to the various physical-chemical mechanisms involved in bacteria removal in constructed wetlands such as solar irradiation and temperature, filtration and adsorption and subsequent sedimentation (Green et al., 1997; Davies \& Bavor, 2000; Zdragas et al. 2002; Arias et al. (2003); Stevik et al., 2004). Although there were no significant reductions in faecal bacteria between the different seasons, the vegetated wetlands were significantly more efficient $(\mathrm{P}<0.05)$ than the non-vegetated control in the reduction of parameters including total coliforms in the dry season of the first year, and faecal streptococci and faecal coliforms in the rainy seasons of the same year. The absence of the significant differences $(\mathrm{P}>0.05)$ between the non-vegetated control and the vegetated wetland in the removal of faecal streptococci during the dry season of the first year, could be an indication that the root system of the plants was not yet well established. But during the rainy season of the second year, it could also indicate that this species is much more influential not only in faecal streptococci removal, but in faecal coliform removal during the first year than in the second year. This explains the absence of significant differences $(P>0.05)$ between the non-vegetated control and the vegetated wetlands for the removal of all the faecal bacteria during the rainy season of the second year. Despite the high removal efficiencies recorded in the vegetated wetlands (between $75 \%$ and 94\%), the faecal bacteria counts in the outflow was sometimes still more than $1000000 \mathrm{CFU} / 100 \mathrm{ml}$. This value is beyond the recommended levels of $\leq 1000 \mathrm{CFU} / 100 \mathrm{ml}$ for wastewater discharge and reuse (IWA, 2000). These suggest the construction of vegetated beds in series to meet with the recommended levels for discharge and reused in agriculture. The vegetated bed with E. crus-pavonis was most efficient in the removal of faecal coliforms generally followed by total coliforms. These results are similar to the results of Lekeufack et al., 2012) using E. pyramidalis in a similar system. The best performances of the bed occurred in the dry seasons, although with no significant differences with the rainy seasons.

The passage of wastewater through the different wetlands in different seasons resulted in the reduction of different contaminants to considerable levels; however, the presence of vegetation further improved the efficiency in the vegetated wetland compared to the non-vegetated control. This can again be attributed to the fact that, the plants produce root exudates which enhanced microbial density and thus their pollutant degradation activity in the wetland (Weißner et al., 
2002; Gagnon et al., 2007). The average $\mathrm{BOD}_{5}$ removal rate in the control wetland (29\%) was significantly lower $(P<0.05)$ than in the vegetated wetland $(46 \%)$. Often, sedimentation, adsorption and microbial metabolism are usually considered as the primary mechanisms of BOD removal in wastewaters, it is likely that the roots of the plants and the many falling leaves in the rainy seasons provided more selling medium than the gravel alone in the non-vegetated control. At the same time these plant material increase the food source for the proliferation of microbial population for biodegradation (Karathanasis et al., 2003).

Although the removal efficiencies of the nutrients were always higher in the vegetated wetland than in the non-vegetated control, there were no significant differences between them. The removal of nutrients (nitrates and phosphates) in wetlands is by plants and microbial uptake where inorganic nutrients are converted to organic biomass (Greenway, 2005). Although other authors have reported the high removals of phosphorus species than the nitrogen species in vegetated systems (Sooknah and Wilkie, 2004; Henry-Silva and Camargo, 2006; Lekeufack et $a l ., 2012$ ); the present work instead revealed a non-significant higher removal of nitrogen species than the phosphorus species in the vegetated bed.

The removal rates of TSS were in most seasons higher but not significant in the vegetated beds than in the non-vegetated control. This was similar to the observations of Karathanasis et al., 2003) in polycultured systems, but contradictory to the results published by Thomas et al. (1995) where the removal efficiency was higher in non-vegetated control.

\section{Conclusion}

The vegetated bed with E. crus-pavonis was most significantly efficient in the removal of faecal coliforms throughout the two years of study followed by the total coliforms, compared to the non-vegetated control. The age of the vegetated bed generally did not have any positive influence in the removal of faecal indicators from wastewater and showed the best efficiencies during the first year. The presence of vegetation in the constructed wetland significantly increased the performance of the wetland in removal of $\mathrm{BOD}_{5}$ from wastewater. The presence of E. crus-pavonis in bed highly influenced the removal of faecal bacteria and the reduction of physicochemical characteristics of wastewater; highly suggesting the recommendation of this macrophyte for use in constructed wetland technologies for domestic wastewater treatment.

\section{Acknowledgment}

The authors thank the International Foundation for Science (IFS) for financial support to the corresponding author through the grants $\mathrm{N}^{\circ} \mathrm{W} / 3782-1$ and $\mathrm{N}^{\circ} \mathrm{W} / 3782-2$.

\section{References}

Agendia, P. L. (1995). Treatment of sewage using aquatic plants: Case of Biyem-Assi domestic sewage (Yaoundé). PhD Thesis. University of Yaoundé I. 154 Pages

Andrews, J. H., \& Haris R. F. (2000). The ecology and biogeography of micro-organisms on plant surfaces. Annual Review of Phytopathology, 38,145-180. http://dx.doi.org/10.1146/annurev.phyto.38.1.145 


\section{$\Lambda$ Macrothink}

Journal of Biology and Life Science ISSN 2157-6076 2013, Vol. 4, No. 2

APHA, (1998). Standard Methods for the Examination of Water and Wastewater. 20th edition. Washington, DC, USA.

Arias, C. A., Cabello A., Brix H., \& Johansen N. H. (2003). Removal of indicator bacteria from municipal wastewater in an experimental two-stage vertical flow constructed wetland systems. Water Science and Technology, 48, 35-41.

Brix, H., 1999. Functions of wetlands macrophytes in constructed wetlands. Water Science and Technology, 29, 71-78.

CEAC, (2005). Recherche et dénombrement des coliformes totaux, entérocoques, coliformes fécaux (thermotolérants) et confirmations à l'espèce Escherichia coli : méthode par filtration sur membrane. Edition 2003-12-05 et Révision 2005-12-15 (2).

Davies, C. M., \& Bavor H. J. (2000). The fate of storm water-associated bacteria in constructed wetland and pollution control pond systems. Journal of Applied Microbiology, 89, 349-370. http://dx.doi.org/10.1046/j.1365-2672.2000.01118.x

Denny, P. (1997). Implementation of constructed wetlands in developing countries. Water Science and Technology, 35, 27-34. http://dx.doi.org/10.1016/S0273-1223(97)00049-8

Fonkou, T., Agendia P. L., Kengne I. M., Amougou A., Focho D. A., Nya J., \& Dongmo F. (2005a). Heavy metals concentrations in biotic and Abiotic components of the Olézoa wetland (Yaoundé- Cameroon, West Africa). Water Quality Research Journal of Canada, 40, 457-461.

Fonkou, T, Nguetsop V. F., Pinta J. Y., Dekoum V. M., Lekeufack M., \& Amougou A. (2005b). Macropyte diversity in polluted and non-polluted wetlands in Cameroon. Cameroon Journal of Experimental Biology, 01,26-33.

Fonkou, T., Sako I. B., Lekeufack M., Mekontso T. F., \& Akoa A. (2011). Potential of Cyperus papyrus in yard-scale horizontal flow constructed wetland for wastewater treatment in Cameroon. Universal Journal of Environmental Research and Technology, 01,160-168.

Gagnon, V., Chazarenc F., Comeau Y., \& Brisson J. (2007). Influence of macrophyte species and microbial density and activity in constructed wetlands. Water Science and Technology, 56, 249-254. http://dx.doi.org/10.2166/wst.2007.510

Green, M. B., Griffin P., Seabridge J. K., \& Dhobie D. (1997). Removal of bacteria in subsurface flow wetlands. Water Science and Technology, 35, 109-116. http://dx.doi.org/10.1016/S0273-1223(97)00059-0

Greenway, M. (2005). The role of constructed wetlands in secondary effluent treatment and water reuse in subtropical and arid Australia. Ecological Engineering, 25, 501-509. http://dx.doi.org/10.1016/j.ecoleng.2005.07.008

Hach, (2004). The Handbook. DR/2500 laboratory spectrophotometer. Procedure manual. $4^{\text {th }}$ Edition. HACH® Be Right ${ }^{\mathrm{TM}}$.

Hammer, D. A. (1989). Constructed Wetlands for Wastewater Treatment: Municipal, Industrial and Agricultural. Lewis Publishers, Chelsea. 406 Pages. 


\section{Macrothink}

Hench, K. R., Bissonnette, G. K., Sexstonea, A. J., Coleman, J. G., Garbutt, K., \& Skousen J. G. (2003). Fate of physical, chemical, and microbial contaminants in domestic wastewater following treatment by small constructed wetlands. Water Research, 37, 921-927. http://dx.doi.org/10.1016/S0043-1354(02)00377-9

Henry-Silva, G. G., \& Camargo A. F. M. (2006). Efficiency of aquatic macrophytes to treat Nile Tilapia pond effluents. Science in Agriculture. (Piracicaba, Braz.), 63, 433-438.

Holm, L. G., Plucknett D. L., Pancho J. V., \& Herberger J. P. (1977). The World's Worst Weeds: Distribution and Biology. 1st Edn.,. University Press of Hawaii,. Honolulu,

Ingersoll, T. L., \& Baker L.A. (1998). Nitrate removal in wetland microcosms. Water Research, 32, 677-684. http://dx.doi.org/10.1016/S0043-1354(97)00254-6

International Water Association (2000). Constructed wetlands for pollution control: processes, performance, design and operation. IWA Specialist Group on Use of Macrophytes in Water Pollution Control. IWA Publishing, London, UK.

Kadlec, R. H., \& Knight R. L. (1996). Treatment Wetlands. Lewis Publishers. New York.

Karathanasis, A. D., Potter C. L., \& Coyne M. S. (2003). Vegetation effect on faecal bacteria, BOD and suspended solid removal treating domestic wastewater. Journal of Ecological Engineering, 20, 157-169. http://dx.doi.org/10.1016/S0925-8574(03)00011-9

Karim, M. R., Glenn E. P., \& Gerba C. P. (2008). The effect of wetland vegetation on the survival of Escherichia coli, Salsmonella typhimurium, bacteriophage MS-2 and polio virus. Journal of Water and Health, 6,167-175. http://dx.doi.org/10.2166/wh.2008.024

Karpiscak, M. M., Gerba C. P., Watt P. M., Foster K. E., \& Falabi J. A. (1996). Multi-species plant systems for wastewater quality improvements and habitat enhancement. Water Science and Technology, 33(10-11), 231-236. http://dx.doi.org/10.1016/0273-1223(96)00424-6

Karjalainen, H., Stefansdottir G., Tuominen L., \& Kairesalo T. (2001). Do submersed plants enhance microbial activity in sediments? Aquatic Botany, 06, 1-13. http://dx.doi.org/10.1016/S0304-3770(00)00138-8

Kengne, I. M., Brissaud F., Amougou A., Eteme R. A., Nya J., Ndikefor A., \& Fonkou T. (2003). Mosquito development in a macrophyte-based wastewater treatment plant in Cameroon (Central Africa). Ecological Engineering, 21, 53-61. http://dx.doi.org/10.1016/S0304-3770(00)00138-8

Kern, I., \& Idler C. (1991). Treatment of domestic and agricultural wastewater by Reed Bed $\begin{array}{llll}\text { systems. } & \text { Ecological 13-25. }\end{array}$ http://dx.doi.org/10.1016/S0925-8574(98)00051-2

Kivaisi, A. K. (2001). The potential for constructed wetlands for wastewater treatment and reuse in developing countries: A review. Ecological Engineering, 16, 545-560. http://dx.doi.org/10.1016/S0925-8574(00)00113-0

Lekeufack, M., Fonkou T., Pamo T. E., \& Akoa A. (2012). Removal of faecal bacteria and 
nutrients from domestic wastewater in a horizontal surface flow wetland vegetated with Echinochloa pyramidalis. African Journal of Environmental Science and Technology, 6, 337-345.

Lester, J. N., \& Birkett J. W. (1999). Microbiology and Chemistry for Environmental Scientists and Engineers. 2nd Edn., E and FN Son,. London and New York. .

Liu, J., C. Qui, Wiao B., \& Cheng Z. (2000). The role of plants in channel-dyke and field irrigation systems for domestic wastewater treatment in an integrated eco-engineering system. Ecological Engineering, 16, 235-241. http://dx.doi.org/10.1016/S0925-8574(00)00061-6

Lorion, R. (2001). Constructed wetlands: Passive systems for wastewater treatment. Technology Status. Report Prepared for the USEPA Technology Innovation Office under a National Network of Environment Management Studies Fellowship, pp: 24.

Mankin, K. R. (2003). Wetlands as treatment systems. In: Encyclopaedia of Water Science, Markel-Dekker, Inc., New York, USA, pp: 1038-1043.

Morel, M. A. (1996). L'utilité Des Végétaux Aquatiques Pour Le Traitement Des Eaux Usées Sous Climat Tropical. Thèse de Doctorat, INPL, Ecole Nat. Sup. d'Agr. et des Ind. Al., France, Pages: 168

Morison, J. I. L., Piedate M. T. F., Muler E., Long S. P., Junk W. J., \& Jones M. B. (2000). Very high productivity of the $\mathrm{C}_{4}$ aquatic grass Echinochloa polystachya in the Amazon floodplain confirmed by net ecosystem $\mathrm{CO}_{2}$ flux measurements. Oecologia, 125, 400-411. http://dx.doi.org/10.1007/s004420000464

Reed, S. C., Crites R. W., \& Middlebrooks E.J. (1995). Natural Systems for Wastewater Management and Treatment. $2^{\text {nd }}$ Edn., McGraw-Hill Inc., New York

Sooknah, R. D., \& Wilkie A. C. (2004). Nutrient removal by floating aquatic Macrophytes cultured in anaerobically digested flushed dairy manure wastewater. Journal of Ecological Engineering, 22, 27-42.

Stevik, T. K., Aa K., Ausland G., \& Hanssen J. F. (2004). Retention and removal of pathogenic bacteria in wastewater percolating through porous media: A review. Water Research, 38, 1355-1367. http://dx.doi.org/10.1016/j.watres.2003.12.024

Tchobanoglous, G. (1987). Aquatic Plant Systems for Wastewater Treatment: Engineering Considerations. In: Aquatic Plants for Water Treatment and Resource Recovery, Reddy K.R. and W.H. Smith, (Eds.). Magnolian Publishing Inc., Orlando. pp: 27-48.

Thomas, P. R., Glover P., \& Kalaroopan T. (1995). An evaluation of Pollutant removal from secondary treated sewage effluent using a constructed wetland system. Water Science and Technology, 32, 87-93. http://dx.doi.org/10.1016/0273-1223(95)00608-7

Thurston, J. A., Gerba C. P., Foster K. E., \& Karpiscak M. M. (2001). Fate of indicator microorganisms Giardia and Cryptosporidium in two constructed wetlands. Water Research, 35, 1547-1551. http://dx.doi.org/10.1016/S0043-1354(00)00414-0 


\section{Macrothink}

Journal of Biology and Life Science ISSN 2157-6076 2013, Vol. 4, No. 2

Torrens, A., Molle P., Boutin C., \& Salgot M. (2009). Removal of bacterial and viral indicators in vertical flow constructed wetlands and intermittent sand filters. Desalination, 246, 169-178. http://dx.doi.org/10.1016/j.desal.2008.03.050

Weißner, A., Kuschk P., \& Stottmeister U. (2002). Oxygen release by roots of Typha latifolia and Juncus effusus in laboratory hydroponic systems. Acta Biotechnologica, 22, 209-226. http://dx.doi.org/10.1002/1521-3846(200205)22:1/2<209::AID-ABIO209>3.0.CO;2-O

Wetzel, R. G. (2000). Fundamental processes within natural and constructed wetland ecosystems: Short Vs long term objectives. Proceedings of the $7^{\text {th }}$ International Conference on Wetland Systems for Water Pollution Control, Vol. 1, November 11-16, 2000, Lake Buena Vista, Florida, PP: 425-440.

Wolverton, B. C. (1987). Aquatic plants for wastewater treatment: an overview. In: Aquatic Plants for Water Treatment and Resource Recovery, Reddy K.R. and W.H. Smith, (Eds.). Magnolian Publishing Inc., Orlando. P. 3-16.

Zdragas, A., Zalidis G. C., Takavakoglou V., Katsavouni S., Anastasiadis E. T., Estridge K., \& Panoras A. (2002). The effect of environmental conditions on the ability of constructed wetlands to disinfect municipal wastewaters. Environmental management, 29, 510-515. http://dx.doi.org/10.1007/s00267-001-0010-6

\section{Copyright Disclaimer}

Copyright reserved by the author(s).

This article is an open-access article distributed under the terms and conditions of the Creative Commons Attribution license (http://creativecommons.org/licenses/by/3.0/). 